RETORIKA: Jurnal Ilmu Bahasa, Vol. 1, No.2 Oktober 2015, 319-330

Available Online at http://ejournal.warmadewa.ac.id/index.php/jret

\title{
DINAMIKA PEMBENTUKAN KATA BAHASA INDONESIA
}

\author{
I Wayan Simpen \\ Universitas Udayana \\ wyn.simpen8@yahoo.com
}

\begin{abstract}
Abstrak
Bahasa Indonesia sebagai salah satu bahasa di dunia tidak mungkin mempertahankan kemurnian dan kemandiriannya. Bahkan, bahasa Indonesia tergolong bahasa yang tidak murni karena dari awal kelahirannya tidak ada bahasa Indonesia. Istilah Indonesia baru muncul belakangan. Tilikan terhadap dinamika pembentukan kata bahasa Indonesia bertolak dari dua sudut pandang. Pertama, sudut pandang internal, yaitu sudut pandang yang terfokus pada kaidah pembentukan kata yang ada dalam sistem bahasa Indonesia. Kedua, sudut pandang eksternal, yaitu sudut pandang yang menekankan pembentukan kata dari pengaruh bahasa lain, baik asing maupun lokal. Proses pembentukan kata secara internal yang lazim terjadi dalam bahasa Indonesia mencakup: afiksasi, reduplikasi, pemajemukan, pemendekan, dan derivasi balik. Dari beberapa pembentukan kata ini, tidak semua dianalisis tetapi hanya dikhususkan pada pembentukan kata yang dinamis (mengalami pasang surut). Hasil pengkajian membuktikan bahwa pembentukan kata dalam bahasa Indonesia dewasa ini, senantiasa mengalami dinamika. Kecenderungan dinamika mengarah pada munculnya afiks asing atau afiks bahasa serumpun, penanggalan afiks, munculnya leksikal baru, dan menyusutnya pemakaian kata yang sebelumnya sangat tinggi. Di sisi lain, ada kecenderungan bahwa morfem unik berubah menjadi morfem bebas.
\end{abstract}

Kata Kunci: Proses pembentukan kata

\begin{abstract}
Indonesian as a language in the world is impossible to maintain its purity and independence. In fact, Indonesian language is classified as a language that is not pure since in the beginning of birth, there was not Indonesian language. Indonesian term emerged recently. Insight on the dynamics of the formation of Indonesian words starting from two points of view. First, an internal viewpoint, namely viewpoints focused on the existing rules of word formation in the Indonesian system. Second, an external viewpoint, the viewpoint that emphasizes the formation of words from the influence of other languages, both foreign and domestic. Internal process of word formation which is prevalent in Indonesian includes: affixation, reduplication, compounding, shortening, and derivation behind. From some of these word-formation, not all analyzed but only devoted to the establishment of a dynamic word (ups and downs). Results of the study proved that the establishment of the Indonesian word for today, in constant dynamics. The tendency of the dynamics leading to the emergence of foreign affix or affixes cognates, affix calendar, the emergence of new lexical, and the shrinking of the previous usage of the word is very high. On the other hand, there is a tendency that turned into a unique morpheme free morpheme.
\end{abstract}

Keywords: Process of word formation .

\section{PENDAHULUAN}

Sejak jaman Sapir-Whorf telah disadari bahwa bahasa memiliki hubungan yang amat erat dengan budaya. Di sisi lain, bahasa sebagai wadah budaya tidak dapat dilepaskan dari pemilik budaya yang ber- sangkutan (manusia). Dinamika bahasa senantiasa seiring dengan dinamika budaya. Oleh karena itu, bahasa modern atau bahasa primitif berkorelasi dengan masyarakat modern atau masyarakat primitif. 
Ditilik dari hubungan bahasa dan manusia atau bahasa dan budaya, tampaknya tidak arif kalau dimunculkan istilah bahasa modern atau bahasa primitif. Bahasa hanya mewadahi budaya penuturnya. Barangkali, istilah manusia modern dan manusia primitif mungkin lebih tepat.

Dinamika manusia dengan segala kemajuannya, baik dalam bidang ilmu, teknologi, dan seni tidaklah sama. Beberapa bangsa mengalami kemajuan yang pesat dan yang lainya agak lambat. Bangsa yang lebih maju dapat dengan mudah mempengaruhi, menguasai, dan bahkan menjajah bangsa yang terbelakang. Kisah penjajahan yang terjadi di muka bumi selalu bermula dari adanya unsur kekuasaan yang dilatari oleh kemajuan dalam segala bidang.

Hanya bangsa yang unggul (dalam segala bidang) yang dapat menghegemoni bangsa lain. Sejalan dengan cengkraman kuasa bangsa penjajah, bahasa penguasa pun merasuk ke dalam bahasa terkuasa. Disadari atau tidak, disukai atau tidak bahasa penguasa sedikit demi sedikit ikut mewarnai bahasa terjajah.

Menyadari akan ketidakberdayaan bangsa terjajah, lahirlah sikap untuk mendewakan penguasa, termasuk bahasanya. Segala sesuatu dari penguasa dianggap maju, modern, dan paling terhormat. Contoh kecil ini dapat dicermati dari fe- nomena yang ada di Bali dan Lombok. Istilah atau kata-kata Jawa bagi orang Bali adalah sesuatu yang mulia dan luhur. Itulah sebabnya istilah Jawa ceker'kaki' (biasa atau mungkin kasar) menjadi cokor'kaki' adalah bahasa Bali Alus. Demikian pula kata dahar'makan' dalam bahasa Sasak, adalah bahasa yang sangat halus. Padahal, kata daar/dahar'makan' dalam bahasa Bali adalah kata-kata biasa (Baca bahasa Bali Kepara).

Sebagai mahluk sosial, manusia tidak bisa hidup tanpa bergantung dengan manusia lain. Manusia senantiasa membutuhkan kehadiran manusia lain, baik dalam etnis, bangsa, maupun lintas bangsa. Adanya hubungan manusia yang demikian itulah menyebabkan keterkaitan antarbahasa tidak terhindarkan. Hubungan manusia yang multikompleks berdampak pada peristiwa bahasa seperti alih kode, campur kode, dan bahkan campur bahasa. Jadi, tidak ada bahasa yang bisa hidup secara murni tanpa adanya susupan bahasa lain, baik pada tataran bunyi, bentuk kata, maupun gramatikal.

Bahasa Indonesia sebagai salah satu bahasa di dunia tidak mungkin mempertahankan kemurnian dan kemandiriannya. Bahkan, bahasa Indonesia tergolong bahasa yang tidak murni karena dari awal kelahirannya tidak ada bahasa Indonesia. Istilah Indonesia baru muncul belakangan. Untuk memberi identitas bangsa yang baru 
lahir itulah disebut bahasa Indonesia, yaitu sebuah bahasa yang cikal bakalnya adalah bahasa Melayu.

Masuknya unsur-unsur bahasa asing telah terjadi jauh hari sebelum bahasa Melayu bermetamorfose menjadi bahasa Indonesia. Peradaban India melalui masuknya Agama Hindu ke Indonesia menjadi bukti, bahwa unsur asing telah merasuk ke dalam khazanah bahasa Melayu. Tradisi ini kemudian berlanjut pada masa penjajahan yang berdampak pada masuknya unsur budaya Eropa melalui bahasa Belanda.

Di antara tataran bahasa yang ada, tataran leksikallah yang paling longgar karena tataran ini paling gampang dipengaruhi. Artinya, pengaruh bahasa asing dalam suatu bahasa paling mudah dilacak dalam sistem leksikalnya. Kata atau istilah tertentu dapat dengan mudah diindentifikasi keasliannya. Sementara itu, sistem gramatikal merupakan sistem yang paling tertutup. Sistem ini diduga (belum ada penelitian yang memadai) menjadi indikator penuturnya, baik sifat, cara berpikir, pola hidup, maupun cara pandang dunia penuturnya.

Tilikan terhadap dinamika pembentukan kata bahasa Indonesia bertolak dari dua sudut pandang. Pertama, sudut pandang internal, yaitu sudut pandang yang terfokus pada kaidah pembentukan kata yang ada dalam sistem bahasa Indonesia.
Kedua, sudut pandang eksternal, yaitu sudut pandang yang menekankan pembentukan kata dari pengaruh bahasa lain, baik asing maupun lokal.

\section{KONSEP DAN KERANGKA TEORI DINAMIKA PEMBENTUKAN KATA SECARA INTERNAL}

Setiap bahasa di dunia, memiliki cara yang khas dalam pembentukan katanya. Kekhasan itu bergantung pada tipe dan rumpun bahasa yang bersangkutan. Artinya, setiap bahasa yang serumpun atau setipe akan memilki cara pembentukan kata yang hampir sama. Demikianlah, bahasabahasa yang berumpun Austronesia akan berbeda dengan bahasa rumpun Melanesia atau yang lainnya. Bahasa tipe Aglutinasi berbeda dengan bahasa tipe Isolatif.

Para ahli mencatat beberapa proses pembentukan kata yang umum terjadi pada bahasa-bahasa di dunia. Misalnya, Huddleston (1984: 22-25) mengemukakan bahwa perubahan morflogis mencakup: pemajemukan, afiksasi, konversi, derivasi balik, perubahan bunyi, suplesi, perpaduan, dan pengakroniman. Grady (1987: 134-132), mengatakan bahwa perubahan morfologis (baca pembentukan kata) mencakup: afiksasi, reduplikasi, pemajemukan, konversi, pemangkasan, pengakroniman, perpaduan, derivasi balik, dan penganamatopeaan. Kridalaksana (1988: 56，1992: 12) ber- 
pendapat bahwa, pembentukan kata terdiri atas: derivasi balik, derivasi zero, afiksasi, reduplikasi, pemendekan, dan perpaduan. Mamkjaer (1991: 319) dengan mengutip Marchand (1969: 2) menyebutkan bahwa proses morfologis mencakup: pemajemukan, afiksasi, derivasi zero, derivasi balik, perpaduan, pemangkasan, dan pengakroniman.

Proses pembentukan kata secara internal yang lazim terjadi dalam bahasa Indonesia mencakup: afiksasi, reduplikasi, pemajemukan, pemendekan, dan derivasi balik. Dari beberapa pembentukan kata ini, tidak semua dianalisis tetapi hanya dikhususkan pada pembentukan kata yang dinamis (mengalami pasang surut).

\section{PEMBAHASAN}

\section{DINAMIKA PEMBENTUKAN KATA}

\section{PADA ASPEK AFIKSASI}

Salah satu ciri bahasa bertipe Aglutinasi adalah pembentukan kata lebih banyak melalui afiksasi. Ini terjadi hampir pada sebagian besar bahasa-bahasa yang ada di Nusantara. Namun, untuk beberapa bahasa di NTT, Indonesia bagian timur, dan Papua, tampaknya ciri ini mulai memudar karena ada sejumlah bahasa yang sangat miskin afiksasinya. Misalnya, bahasa Kambera di Sumba Timur, bahasa Kodi di Sumba Barat, bahasa Sabu, bahasa Woleo di Sulawesi dan lain-lain. Tampkanya, bahasa -bahasa di Indonesa dapat digolongkan ke dalam tiga kelompok, yaitu kelompok Austronesia Barat, Austronesia Tengah, dan Austronesia Timur. Kelompok Austronesia Timur hidup berdampingan dengan rumpun Melanesia, khususnya di Papua.

Ragam bahasa Indonesia yang mendominasi atau dijadikan acuan masyarakat penutur bahasa Indonesia adalah "ragam bahasa Indonesia ibu kota". Bahasa Indonesia Jakarta menjadi model bagi standardisasi pemakaian bahasa Indonesia karena Jakarta dianggap sebagai sumber dari semua sumber, termasuk bahasa Indonesia yang dianggap standar.

Kemajuan teknologi informasi dan laju perkembangan jejaring sosial mempersempit jarak bumi, termasuk jarak Jakarta dengan daerah lain di Indonesia. Itulah sebabnya segala sesuatu yang terjadi di belahan dunia lain, dapat dengan mudah diakses dalam hitungan detik. Demikianlah kata atau istilah baru yang muncul di Jakarta akan dengan cepat menyebar ke seluruh penjuru tanah air.

Penelitian ini tidak hanya terfokus pada pembentukan kata yang dianggap standar, tetapi mencakup pula kata atau istilah yang populer (baca gaul), dan untuk kata-kata ini tampkanya tidak perlu disikapi secara berlebihan. Bahasa itu ibarat pakaian, kalau tepat pemakaiannya tentu tidak perlu dirisaukan. Sikap penulis bukan 
sebagai pembina bahasa, melainkan sebagai peneliti bahasa. Oleh karena itu, kajian ini tidak mempersoalkan apakah pembentukan kata itu baku atau tidak, yang penting kata itu ada atau tidak.

Ketika pertama kali istilah galau dan lebai muncul di televisi, sebagian dari kita mungkin tercengang. Kreativitas penciptanya sangat berjasa bagi pengayaan leksikon penutur bahasa Indonesia karena kata ini dapat disandingkan dengan kata: cemas, resah, gelisah, sedih, dan risau. Setiap kata memiliki komponen makna tersendiri, sehingga tidak ada kata yang bernar-benar bersinonim. Demikianlah kata galau sangat pas digunakan untuk menyatakan sikap hati penutur dan kata ini tidak tergantikan oleh kata sandingannya.

Kata lebai yang berarti 'pegawai masjid atau orang yang mengurus sesuatu pekerjaan yang bertalian dengan agama Islam di dusun; orang yang selalu sial atau malang, tentu sangat berbeda maknanya dari kata lebai yang dipahami dalam dunia intertaimen. Misalnya, dalam kalimat" Wah kamu terlalu lebai", "Begitu saja kamu sudah lebai", atau "Dasar manusia lebai" dan seterusnya.

Perkembangan pembentukan kata bahasa Indonesia juga diwarnai oleh masuknya afiks asing atau afiks bahasa serumpun. Sufiks -in dari bahasa Melayu Betawi yang semula dipakai oleh penutur bahasa Indonesia di Jakarta, menyebar ke seluruh pelosok tanah air. Tidak mengherankan kalau kata: rasain, ngapain, kerjain, dudukin, besarin, kecilin, syukurin, dan lain muncul dalam pemakaian bahasa Indonesia saat ini. Tampaknya, kata-kata ini bersaing dengan bentuk: rasakan, mengapa, kerjakan, diduduki, dibesarkan, dikecilkan, dan disyukuri. Hal yang sama juga pernah diungkap oleh Kridalaksana (1992: 58).

Pembentukan kata dewasa ini juga ditandai oleh adanya penanggalan afiks atau nasalisasi, seperti tampak di bawah ini.

$\begin{array}{ll}\text { Bentuk lengkap } & \text { Bentuk Baru/tidak lengkap } \\ \text { Bekerja } & \text { kerja } \\ \text { Menulis } & \text { nulis } \\ \text { Menyontek } & \text { nyontek } \\ \text { Menuduh } & \text { nuduh } \\ \text { Menari } & \text { nari } \\ \text { Membawa } & \text { bawa } \\ \text { Menguliti } & \text { ngulitin }\end{array}$


Ada pula kecenderungan memanfaatkan afiks asing seperti afiks -ization dan ir, yang masing berpadanan dengan isasi dalam bahasa Indonesia. Beranalogi dari bentuk organisasi dan reboasasi kemudian lahir kata-kata: lamtoronisasi, gotisasi, vavingisasi, pagarisasi, aspalisasi, dan seterusnya, yang ternyata bersanding dengan bentuk: pelamtoroan, pengegotan, pemavingan, pemagaran, dan pengaspalan.

Di sisi lain, bentuk-bentuk yang semestinya menggunakan sufiks -isasi, ternyata masih dibiarkan dalam bentuk aslinya. Misalnya, mendramatisir, melokalisir, mengisolir, mentolelir, mengorganisir, dan mengkonfrontir. Bentuk-bentuk semacam ini diduga berasal dari bahasa Belanda, dan bentuk yang danggap baku dalam bahasa Indonesia adalah: mendramatisasi, melokalisasi, mengisolasi, mentoleransi, mengorganisasi, dan mengkonfrontasi.

Dewasa ini, juga berkembang pemakaian afiks atau kata asing walaupun dalam bahasa Indonesia sudah ada kata atau istilah yang dianggap lebih pas. Misalnya, kata disabel, afiks $a$, in/im-, pro-, kontra, dan lain-lain. Kata disabel adalah istilah asing yang terbentuk dari unsur dis

Bentuk lama

Memperkirakan

Mempengaruhi

Mensinyalir 'tidak' dan abel 'mampu'. Ternyata, kata ini muncul untuk menggantikan kata tuna'kurang/tidak mampu, yang lazim ditemukan dalam komposisi tuna netra, tuna rungu, tuna grahita, tuna daksa, tuna wisma, tuna karya, tuna susila. Padahal, awal kemunculan kata ini dimaksudkan untuk memberikan efek lebih sopan untuk istilah buta, tuli, dan lain-lain. Sekarang, gabungan kata tuna netra diganti dengan disabel netra dan ada kecenderungan untuk menyebut penyandang cacat sebagai anak-anak berkebutuhan khusus.

Di sisi lain, afiks a-.in/im, kontra-, dan pro- juga dimaksudkan untuk memperhalus tuturan dan ada kecenderungan untuk mengaburkan makna kata yang dibubuhi imbuhan itu karena tidak semua penutur paham akan arti afiks dimaksud yang sesungguhnya. Misalnya, kata amoral, inpoten, kontrarevolusi, dan prolemerdekaan.

Lima tahun belakangan ini, ada kecenderungan pembentukan kata, khususnya yang berkaitan dengan prefiks meN- atau peNtaat asas dengan aturan. Perubahan yang drastis menyebabkan pemakai bahasa belum terbiasa. Di bawah ini disajikan beberapa kata yang dianggap bentukan baru.

Bentuk Baru

memerkirakan

memengaruhi

menyinyalir 


\section{Mempedulikan \\ Mempopulerkan \\ Memperjuangkan \\ Pendelegasian \\ Pendayagunaan}

Beanalogi dari bentukan baru ini, muncullah bentuk-bentuk berikut ini, yang barangkali menyimpang dari aturan. Setahu

\section{Bentuk lama \\ Mentradisi \\ Mentraktor \\ Mentraktir \\ Memfitnah \\ Memfasilitasi \\ Memfoto}

DINAMIKA PADA ASPEK PEMAJEMUKAN

Pemajemukan merupakan salah satu pembentukan kata dalam bahasa Indonesia yang cukup produktif. Para ahli masih silang pendapat mengenai pemajumukan ini, terutama dikaitkan dengan frase. Beberapa sumbangan pemikiran terangkum dalam simposium Tatabahasa Lembaga Linguistik Fakultas Sastra, Universitas Indonesia (Masinambow (Peny.), 1980).

Penelitian ini tidak bermaksud untuk mengungkit lagi persoalan di sekitar kata majemuk. Akan tetapi, prinsip dasar yang dipegang dalam penelitian ini adalah kata majemuk berbeda dengan frase, kata majemuk dibangun oleh unsur bebas-bebas, bebas terikat, terikat-bebas, dan bebas-
memedulikan
memomulerkan
memerjuangkan
penelegasian
penayagunaan

saya bentuk-bentuk ini tidak mengalami peluluhan

Bentuk Baru
menradisi
menraktor
menraktir
memitnah
memasilitasi
memoto

unik. Dari sudut makna, ada kata majemuk yang menyatakan satu-kesatuan makna, (ada makna pusat dan atribut) dan ada yang menimbulkan makna baru (semua unsur kehilangan identitas). Dari segi hubungan, ada endosentris dan ada yang eksosentris.

Dewasa ini, penutur bahasa Indonesia cenderung memandang bahwa kata majemuk dengan unsur morfem unik bukanlah bentuk majemuk lagi karena bentuk yang semula dianggap unik karena hanya melekat pada bentuk tertentu saja, ternyata bisa berdiri bebas. Perhatikan kecenderungan pemakai bahasa Indonesia saat ini.

(a). Meskipun usianya muda belia ia sudah berpenghasilan tinggi.

(b). Sudah tua renta masih pula suka dengan gadis muda. 
(c). Hujan deras itu membuat ia basah kuyup.

(d). Pemuda yang kulitnya hitam pekat itu adalah pacar teman saya.

(e). Sekitar bulan April di NTT sudah kering kerontang.

(f). Nenek moyang kita adalah seorang pelaut.

Unsur belia, renta, kuyup, pekat, dan kerontang adalah unsur pembentuk kata majemuk yang ditemukan dalam kalimat di atas. Semua unsur itu disebut morfem unik karena hanya dapat melekat pada bentuk: muda, tua, basah, hitam, dan kering. $\mathrm{Na}-$ mun, siapa menyangka ternyata bentukbentuk di bawah ini dijumpai dalam pemakaian.

(a). Ia menikah dalam usia yang masih belia.

(b). Usia renta tidak menjadi halangan untuk berinovasi.

(c). Dengan pakaian yang kuyup ia bersimpuh di kaki ibunya.

\footnotetext{
Reduplikasi penuh

Rumah sakit-rumah sakit

Meja hijau-meja hijau

Rumah tahanan-rumah tahanan

Rumah cuci-rumah cuci

Rumah makan-rumah makan
}

Bertolak dari konsep head dan modifier, tampaknya perulangan sebagian lebih masuk akal. Apabila kata majemuk mendapat (d). Hanya gigi yang tampak putih karena (ke) pekat (an) kulitnya.

(e). Di tengah bumi yang kerontang masih ada beberapa batang pohon yang menghijau.

(f). Proto Austronesia Purba merupakan moyang bahasa-bahasa Austronesia.

Pembentukan kata tidak hanya terjadi melalui satu proses morfologis, tetapi bisa melalui dua atu tiga proses morfologis. Misalnya, kata yang dibentuk melalui pemajemukan bisa mengalami afiksasi atau reduplikasi. Khusus mengenai reduplikasi kata majemuk, para ahli belum mencapai kata sepakat. Artinya, ada yang berpendapat bahwa kata majemuk jika mengalami reduplikasi harus diulang seluruhnya, tetapi ada juga berpendapat bahwa kata majemuk harus diulang sebagian. Silang pendapat inilah yang membuat pembentukan kata melalui pemajemukan ini sangat dinamis. Perhatikan bentuk-bentuk bersaing di bawah ini

$$
\begin{aligned}
& \text { Reduplikasi Sebagian } \\
& \text { rumah-rumah sakit } \\
& \text { meja-meja hijau } \\
& \text { rumah-rumah tahanan } \\
& \text { rumah -rumah cuci } \\
& \text { rumah-rumah makan }
\end{aligned}
$$

afiksasi sebagian, setiap unsur tetap mempertahankan identitasnya. Dengan kata lain, setiap unsur dipisahkan dari unsur yang 
lain. Hal ini, berbeda jika kata majemuk mendapat prefiks dan sufiks sekaligus, unsur yang semua terpisah harus digabung. Cermati contoh di bawah ini.

Bekerja sama, bukan bekerjasama

Tanggung jawabkan, bukan tanggungjawabkan

Meja hijaukan, bukan mejahijaukan

Antar waktukan, bukan antarwaktukan

Coba bandingkan dengan contoh berikut.

Dikerjasamakan, bukan dikerja samakan

Dipertanggungjawabkan, bukan dipertanggung jawabkan

Dianaktirikan, bukan dianak tirikan Diantarwaktukan, bukan diantar waktukan.

\section{PEMENDEKAN}

Pemendekan merupakan salah satu proses morfologis yang ditemuakn hampir pada semua bahasa di dunia. Pembentukan kata melalui pemendekan dapat dilakukan dengan cara mengambil fonem awal setiap kata, mengambil bagian atau suku setiap kata dan merangkaikannya sehingga menyerupai kata, menyingkat atau memendekkan kata atau bentuk yang sudah ada, baik bagian depannya maupun bagian belakangnya.

Proses pembentukan kata yang dilakukan dengan cara menanggalkan bebera- pa bagian leksem atau kombinasi leksem, oleh Kridalaksana disebut abreviasi (1992: 159). Setiap pemendekan pasti menghasilkan bentuk pendek atau disebut kependekan. Bentuk-bentuk yang tergolong kependekan, tentu memiliki kepanjangan. Artinya, setiap kependekan pasti dapat dikembalikan ke dalam kepanjangannya. Tidak ada kependekan yang tidak punya kepanjangan.

Kridalaksana (1992: 162-163) mencatat beberapa jenis abreviasi seperti tertera di bawah ini.

(a). Singkatan, yaitu salah satu hasil proses pemendekan yang berupa huruf atau gabungan huruf, baik yang dieja huruf demi huruf maupun yang tidak.

(b). Penggalan, yaitu proses pemendekan yang dilakukan dengan cara mengekalkan salah satu bagian leksem, contoh: Prof., dok., Non., pak., dan lain-lain.

(c). Akronim, yaitu proses pemendekan yang dilakukan dengan cara menggabungkan huruf atau suku kata atau bagian lain yang ditulis atau dilafalkan seperti kata yang memenuhi kaidah fonotaktik, contoh: ABRI, PUSDIKLAT, SIDAK, SISKAMLING, SENDRATARI.

(d). Kontraksi, yaitu pemendekan yang dilakukan dengan cara meringkaskan leksem dasar atau gabungan leksem, seperti; tak tidak, tuk----untuk, pun---walaupun, meskipun, tar----sebentar, 
Meskipun pemendekan merupakan gejala umum dalam semua bahasa, tetapi pemendekan yang terjadi dalam pembentukan kata bahasa Indonesia sangatlah produktif. Setiap instansi, golongan, dan bahkan profesi berlomba-lomba membuat singkatan atau akronim. Setakat ini, setahu saya singkatan sangat marak ditemukan pada istitusi tentara dan polisi. Kedua instansi ini bertanggung jawab atas keamanan dan keutuhan negara kesatuan Republik Indonesia. Oleh karena itu, dibutuhkan banyak singkatan atau akronim untuk menjamin kerahasiaan.

Dalam kosa kata bahasa Indonesia, singkatan asing juga tidak bisa ditampik. Misalnya, untuk mengungkapkan perasaan seseorang yang serba tidak menyenangkan, menjengkelkan, menyusahkan, dan mengesalkan digunkan BT. Lalu, untuk seseorang yang memandu jalannya acara digunakan singkatan MC. Seseorang yang dianggap penting disebut VIV, atau VVIV. Pusat pelatihan disebut TC. Orang yang banyak berbiacara tetapi sedikit bekerja disebut NATO.

Namun, yang sangat menarik adalah adanya singkatan asing yang sama dengan singkatan Indonesia, dan kepanjangannya pun sama. Perhatikan singkatan asing ATM, yang memiliki bentuk kepanjangan automatic teller machine. Bandingkan singkatan Indonesia ATM, yang memilki bentuk kepanjangan anjungan tunai mandiri. Entah kebetulan atau tidak, bentuk dan makna singkatan asing sama dengan bentuk dan makna singkatan Indonesia.

Maraknya barang bekas yang melanda Indonesia belakangan ini, membantu kita untuk mengenal singkatan OB. Selidik demi selidik, ternyata OB merupakan singkatan dari obral. Singkatan ini muncul karena semua barang bekas, khususnya pakaian yang datang dari China, Jepang, dan Korea dijual murah, alias diobral. Tiga negara ini memiliki tradisi bahwa pakaian hanya digunakan untuk satu musim.

Hal yang menarik dan mungkin agak menggelikan adalah singkatan atau pemendekan tidak luput dari proses morfologis yang lain. Misalnya, pemendekan juga mengalami afiksasi. Dalam kasus seperti ini, pemendekan berperilaku seperti kata atau bentuk dasar sesungguhnya. Contoh di bawah ini akan memperkaya pengetahuan kita.

(a). Semua tenaga honorer tahun depan akan di-PNS-kan.

(b). Sekolah kejuruan itu sudah lama diSMU-kan.

(c). Penilangan (bentuk dasar tilang) itu dilakukan untuk menjaring pembalap liar.

(d). Karena salah mengambil keputusan, pemerintah bisa di-PTUN-kan.

(e). Apakah adikmu sudah di-SMS?

Maraknya pemakaian singkatan atau 
pemendekan dewasa ini, dipicu oleh kebiasaan masyarakat mengirim pesan singkat melalui telepon selular. Menurut catatan, pemakaian telepon selular di Indonesia sangatlah tinggi karena pemakainya mulai dari usia dini sampai usia lanjut.

\section{SIMPULAN}

Hasil pengkajian membuktikan bahwa pembentukan kata dalam bahasa Indonesia dewasa ini, senantiasa mengalami dinamika. Kecenderungan dinamika mengarah pada munculnya afiks asing atau afiks bahasa serumpun, penanggalan afiks, munculnya leksikal baru, dan menyusutnya pemakaian kata yang sebelumnya sangat tinggi. Di sisi lain, ada kecenderungan bahwa morfem unik berubah menjadi morfem bebas dan kecenderungan ini tidak hanya terjadi dalam bahasa Indonesia, tetapi terjadi pula dalam bahasa-bahasa lokal seperti bahasa Bali.

Dibandingkan dengan bahasa-bahasa lain di dunia, bahasa-bahasa di Indonesia, terutama bahasa Indonesia proses pemendekan sangat tinggi. Hasil pemendekan tidak luput pula dari proses morfologis. Bagi pembelajar asing, pemendekan ini cukup menyulitkan mereka. Bahkan, singkatansingkatan asing pun ikut meramaikan dinamika pembentukan kata dalam bahasa Indonesia.

\section{UCAPAN TERIMAKASIH}

Penulis mengucapkan terima kasih kepada Mitra Bestari atas masukan-masukan yang telah diberikan untuk perbaikan substansi artikel saya ini.

\section{DAFTAR PUSTAKA}

Aronoff, Mark. 1976. Word Formation in Generaive Grammar. Cambridge: Massachusets Institue of Technology, The MIT Press.

Bauer, Laurie. 1988. Introducing Linguistic Morphology. Edinburgh University Press.

Bauer, Laurie. 1983. English Word Formation. Cambridge: Cambridge University Press.

Bybee, Joan. 1985. Morphology: A Study of The Relation Between Meaning and Form.Amsterdam, Philadelphia: John Benyamin Publishing Company.

Chafe, Wallace L. 1970. Meaning and the Structure of Language. Chicago and London; The University of Cicago Press.

Comrie, Bernard. 1976. Aspect: An Introduction to The Study of Verbal and Related Problems Cambridge: Cambridge University Press.

Crystal, David. 1987. (Editor). The Cambridge Encyclopedia of Language.Cambridge: Cambridge University Press.

Dardjowidjojo, Soenjono. 1988. "Morfologi Generatif: Teori dan Permasalahannya" dalam PELLBA 1, Soenjono (Peny.). Jakarta: Lembaga Bahasa Atmajaya.

Dardjoidjojo, Soenjono. 1983. Beberapa Aspek Linguistik Indonesia. Seri ILDEP. Jakarta: Djambatan.

Grady, William O.dkk. 1987-Contemporary Linguistic Analisys: An Introduction.Toronto, A. Longman Company.

Katamba, Francis.1993. Modern linguistic: Morphology. Gerat Britain: Makays Of Cahrtham PLC.

Kridalaksana, Harimurti. 1986. Kelas Kata dalam Bahasa Indonesia. Jakarta., PT Gramedia.

Kridalaksana, Harimurti. 1989. Pembentukan Kata dalam Bahasa Indonesia. Jakarta. Gramedia Pustaka Utama. 
Matthews, P.H. 1974. Morphology: An Introduction to the Theory of Word Structure. London: Cambridge University Press.

Spancer, Andrew. 1991. Morphological Theory: An Introduction to Word Struture in Generative Grammar. Cambridge: Cambridge University Press.

Simpen, I Wayan. 2008. Morfologi: Sebuah Pengantar Ringkas. Denpasar, Udayana University Press. 